\title{
Development of Entrepreneurial Spirit Through Multicultural Approach
}

\author{
Monry Fraick Nicky Gillian Ratumbuysang \\ Economic Education Department \\ Faculty of Teacher Training and Education \\ Universitas Lambung Mangkurat \\ Banjarmasin, Indonesia \\ monryratumbuysang@gmail.com
}

\begin{abstract}
Growing the entrepreneurial spirit is currently very difficult due to the lack of good support from the government on a large scale as well as families on a small scale. Actually entrepreneurship is very easy. It only requires strong determination and the ability to read opportunities. The ability to read opportunities here is able to see opportunities from different aspects of difference. A plural Indonesian society is a huge market for an entrepreneur. Entrepreneur who has a creative and innovative personality, with the characteristics of full confidence, has the initiative, has the motive of achievement, has leadership spirit, and dare to take risks with full calculation In this paper trying to describe the development of entrepreneurial spirit through multicultural approach in Indonesia.
\end{abstract}

Keywords - Entrepreneurial Spirit, Multicultural Approach

\section{INTRODUCTION}

Cooperation minister has given official statement, based on data from BPS, the number of non-agricultural entrepreneurs who settled reached 7.8 million to $3.1 \%$ of the population of 252 million which was previously only $1.67 \%$, Thus the level of entrepreneurship Indonesia has exceeded 2 percent from population, as a minimum requirement of a society will prosper, although still lagging behind other countries such as Malaysia 5 percent, China 10 percent, Singapore 7 percent, Japan 11 percent and US 12 percent. [1]. As the largest country in Southeast Asia, Indonesia is only supported by entrepreneurs less than $5 \%$ of the total population, or just less than 1 million inhabitants of the total population of Indonesia which amounts to 250 million people. This fact is triggered by the desire of most of Indonesia's population, which is still oriented to become civil servants (PNS), which is considered more comfortable than being an entrepreneur [2].

The media is full of stories of successful young entrepreneurs making fortunes from risky and challenging business opportunities. Most successful entrepreneurs, however, are much more deliberate in their decision making. Many factors have been identified as helping to lead to economic success for entrepreneurs. Who influences the decision maker can exert a big influence on the success of a business venture. In a broad sense, the overall sociocultural context exerts a significant impact on the decision-making and risk-taking of entrepreneurs [3]. More specifically, if an entrepreneur runs the business with significant influence from family stakeholders, the business is run in a more risk-averse manner [4]. Conversely, the entrepreneur will run the business in a more risk-tolerant manner if there is significant influence from market-oriented stakeholders [4].

Parents' perception of entrepreneurship is the same as trading, which is clearly different from the true meaning of the entrepreneur. Lack of parental knowledge about the true meaning of entrepreneurship makes employment an entrepreneur greatly avoided. Especially after seeing and hearing the bad experiences of their friends who fail in entrepreneurship makes them close themselves to things entrepreneurial. Efforts to protect their children, parents deliberately send their children to school on a path they deem much more needed in government or to become employees [5]. Actually, Successful entrepreneurs are also motivated by other personality characteristics such as need for achievement, need for cognition, and internal locus of control [6], leadership ability [7] and a connection to support networks [8].

With regard to the need for entrepreneurship skills and skills, according to [9], that entrepreneurship can be learned, and learning about entrepreneurship is important because with entrepreneurship can change the economic strength of a nation and able to unify the differences through organizational learning [2]. How is the best method to train young entrepreneurs to realize that Indonesia is made up of multiculturalism?

Good entrepreneurs are entrepreneurs who are able to read the needs of consumers, and able to find opportunities in many doors and opportunities. The ability to read opportunities, especially in the diversity of Indonesian society is needed. As we know that the Indonesian nation has a very diverse cultural group. From Sabang to Merauke the people have a diversity both character and character. The ability to read opportunities and market their products are the characteristics of a 
successful entrepreneurial spirit. Only people with an entrepreneurial spirit are able to survive in this present era.

\section{LITERATURE REVIEW}

The spirit is something abstract, which is merely a visible statement with the body, or symptoms that appear to be the gesture of being spirit is spirit; every human being has abstract nature and phenomena of feelings, thoughts, dreams, etc [10]. The entrepreneurial spirit which is the life of his life in entrepreneurship is in a position that is the nature and character of someone who has the will to realize innovative ideas into the real world creatively [10]. Entrepreneurship is the spirit of a person expressed through creative and innovative attitude and behavior to perform an activity. Someone who is entrepreneurial spirit is a person who devotes himself and has the spirit of life to always produce and market new products. This entrepreneurial spirit is very appropriate for the bill in the atmosphere of business competition, because in each business competition business people compete to outperform existing products. The presence of new products is a new alternative for consumers. Create more features that are in the new product with the product long requires competent personnel, that is personnel who have the spirit and the ability to outperform competitors when and where. Personnel are a capital that must be built and owned by the company, nation and state for business. This product is new by one manufacturer, but the new product being marketed should have more privilege with the old product market.

Young entrepreneurs who already have a high entrepreneurial spirit will always strive to create new innovations so that the products they produce are no less competitive in the market. To win any competition, most entrepreneurs will make various modifications to the product and improve the marketing strategy of the product so that consumers are interested in the products they offer.

The creative and innovative process is only done by people who have a creative and innovative personality, people with entrepreneurial spirit, attitudes and behaviors, with (1) selfconfident characteristics, the indicators are full of confidence, optimism, commitment, discipline and to be responsible. (2) have initiative, the indicator is full of energy, deft in acting, and active. (3) have achievement motives, the indicators consist of orientation on outcomes and future insights; (4) have leadership spirit, the indicator is dare to be different, trustworthy and tough in acting, and (5) dare to take risk with full calculation (hence likes challenge). The creative and innovative process is only done by people who have a creative and innovative personality, people with entrepreneurial spirit, attitudes and behaviors, with (1) self-confident characteristics, the indicators are full of confidence, optimism, commitment, discipline and to be responsible. (2) have initiative, the indicator is full of energy, deft in acting, and active. (3) have achievement motives, the indicators consist of orientation on outcomes and future insights; (4) have leadership spirit, the indicator is dare to be different, trustworthy and tough in acting, and (5) dare to take risk with full calculation (hence likes challenge).

\section{RESUlt AND Discussion}

In multicultural education, the key word is recognition in the face of differences and rewards, and there is no limit to respecting a particular culture. According to [11], the element of multicultural education includes three values, namely: (1) studying and assessing one's cultural heritage; (2) able to respect each other in learning culture other than its culture and enjoy its own culture; and (3) want to view the existence of unequal cultural groups within a community to be more appreciated, as good and positive to be respected, valued and maintained.

While the multicultural approach is a term used to describe one's view of the diversity of life in the world, or cultural policies that emphasize acceptance of diversity, and the various cultures (multicultural) that exist in people's lives regarding values, systems, cultures, customs, and the politics they profess [12]. Multicultural can also be interpreted as diversity or a difference to a culture with another culture. So that multicultural society can be defined as a group of people who live and live settled in a place that has its own culture and distinctive characteristics that are able to distinguish between one society and the other. Each society will produce its own culture which will be a characteristic for the community. Basically, the multiculturalism that is formed in Indonesia is the result of the wide and varied socio-cultural and geographic conditions. According to geographical conditions, Indonesia has many islands where each island is inhabited by a group of people forming a society. The community forms a culture of society itself. Of course this affects the existence of a very large and diverse culture.

In the concept of multiculturalism, there is a close relationship to the formation of a society based on bhineka tunggal ika and realize a national culture that becomes unifying for the nation of Indonesia. However, in practice there are still many obstacles that prevent the formation of multiculturalism in society.

Implementing an entrepreneurial spirit is in a multicultural approach. The entrepreneurial spirit can be implemented in the diversity of Indonesian society when an entrepreneur runs his business. Someone who has a self-confident entrepreneurial spirit is very confident and optimistic when running their business or developing the business, they are committed, disciplined and responsible for what they say and they run. This is what makes customers feel comfortable when transacting or doing business with them. We'll see where the Padang restaurant can be found all over the archipelago. While we know that Indonesian society consists of various tribes with different tongues and tastes. Capitalized by faith and optimism, they run the business with a full sense of discipline and responsibility.

Young entrepreneurs who have the initiative, they will be very nimble in acting, and active. The cool term is "pick up the ball". They do not hesitate to go directly to their customers. Call it, Bong Candra, a successful businessman and motivator. He did not hesitate to greet his customers who are visiting at his place of business. A successful entrepreneur has an achievement motive; they are result oriented and have 
forward insight. They always ask their customers what items they need and try to find. This is called by looking at opportunities. Like JNE and TIKI express delivery services. A business includes domestic and overseas shipments with customers from all over the country.

The entrepreneurial spirit is incomplete if it does not have a leadership spirit. They dare to be different in order to demonstrate that they are trustworthy and tough in action, and the last is that they dare to take risks in a calculated and likes challenge. An example is Elidawati's mother, Elzatta Founder of 24 Years Exist in Fashion Hijab Business. Now Elzatta has more than 60 stores; 40 partner stores and 23 official stores. Elzatta itself is more focused selling veils. Hijab that takes the material and is manufactured in Turkey has a bright color motif from a soft and glossy material. Although 70 percent produce hijab, but 30 percent still there is a collection of Muslim fashion. Products sold by Elzatta range from Rp 60 thousand to Rp 150 thousand.

\section{CONCLUSION}

The entrepreneurial spirit is one of the innate characteristics of the parents or genetically and can also be trained on a person. For people who have had an entrepreneurial spirit since their childhood (innate), they do not have to bring up the entrepreneurial spirit intensively. In each activity they will show entrepreneurial activities. They tend to work hard, never give up, persevere in the face of trials, and most importantly they will show others that they are self-reliant. This is very contrary when compared with someone who tried to foster entrepreneurial spirit in him. Entrepreneurial spirit can indeed be cultivated to instill in a person. To grow the entrepreneurial spirit through multicultural approach can be done in various ways. Among the ways in which it is intended is by attending a seminar on entrepreneurship and getting to know the people around, often reading biographies of successful people from various quarters, tribes and groups, getting used to being in a place that is unfamiliar to him by way of wander to other areas,, and the most important is to get used to grow mutual care for each other.

\section{REFERENCES}

[1] http://www.depkop.go.id/content/read/ratio-wirausaha-indonesia-naikjadi-31-persen/. Retrieved December 2017

[2] Suryaman, "Pengembangan Konsep Pendidikan Multibudaya Melalui Gemar Belajar, Kreatif, Mandiri, dan Berbudi Pekerti Luhur untuk Membentuk Jiwa Wirausaha di Indonesia", SOSIOHUMANIKA: Jurnal Pendidikan Sains Sosial dan Kemanusiaan, 7(2), 2014.

[3] D. Grichnik, "Risky choices in new venture decisions-Experimental evidence from Germany and the United States", Journal of International Entrepreneurship, 6 (1), 2008, pp 22-47.

[4] D. Miller, I. Breton-Miller, \& R.H. Lester, "Family and lone founder ownership and strategic behaviour: social context, identity, and institutional logics", Journal of Management Studies, 48(1), 2011, pp 125 .

[5] F.N.G.R Monry, A. R. Aliyah, Peranan Orang Tua, Lingkungan, Dan Pembelajaran Kewirausahaan Terhadap Kesiapan Berwirausaha, Downloaded https://journal.uny.ac.id/index.php/jpv/article/view/6058, 2013

[6] D.D. Zhang, \& E. Bruning, "Personal characteristics and strategic orientation: entrepreneurs in Canadian manufacturing companies",
International Journal of Entrepreneurial Behaviour \& Research, 17(1), 2011, pp 82-103

[7] K. Matzler, F. Bailom, M. Anschober, \& S. Richardon, "Sustaining corporate success: What drives the top performers?", The Journal of Business Strategy, 31(5), 2010, pp 4-13.

[8] W. Stam, \& T. Elfring, "Entrepreneurial orientation and new venture performance: The moderating role of intra- and extraindustry social capital", Academy of Management Journal, 51(1), 2008, pp 97.

[9] Kickul and Fayolle, Cornerstones of change: Revisiting and challenging new perspectives on research in entrepreneurship education, In A. Fayolle (Ed.), Cheltenham, UK Northampton, MA: Edward Elgar Publishing.

[10] E. R. Monika and D. Hartanti, Analisis Hubungan Value Based Management dengan Corporate Social Responsibility dalam Iklim Bisnis Indonesia (Studi Kasus Perusahaan SWA100 2006), Simposium Nasional Akuntansi XI, 2008

[11] L. May, S. Collins-Chobanian \& K.Wong [eds], EtikaTerapan I: Sebuah Pendekatan Multikultural, Yogyakarta: PT Tiara Wacana Yogya, Terjemahan, 2001, pp 15-25.

[12] Wikipedia, Multikultural, https://id.wikipedia.org/wiki/Multikulturalisme. 2017
Downloaded 